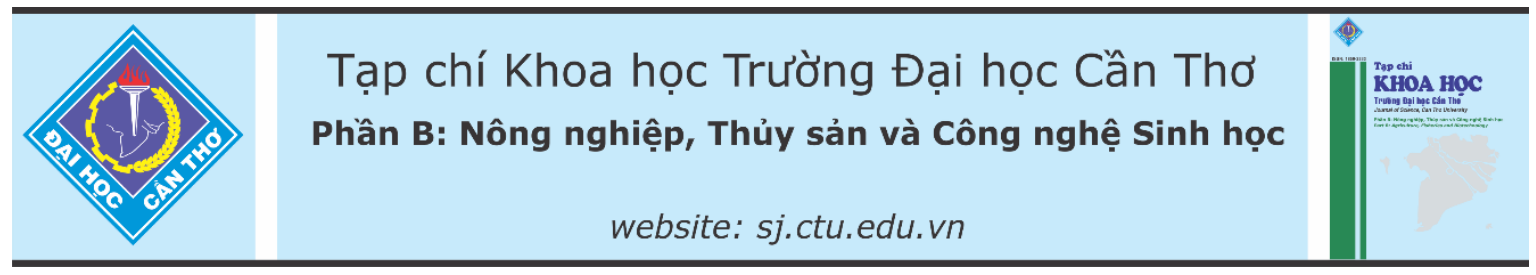

DOI:10.22144/ctu.jvn.2021.042

\title{
PHÂN LẬP VÀ TUYỂN CHỌN MỘT SỐ DÒNG VI KHUẨN TỬ LÁ THỰC VẬT CÓ KHẢ NĂNG KÍCH THÍCH SINH TRƯởNG CÂY TRỒNG
}

\author{
Ung Thanh Nhàn ${ }^{1}$, Nguyễn Thị Kiều Oanh ${ }^{2}$ và Nguyễn Khởi Nghĩa ${ }^{2 *}$ \\ ${ }^{1}$ Học viên cao học ngành Sinh thái học khóa 25, Khoa Khoa học Tụ nhiên, Truờng Đại học Cần Tho \\ ${ }^{2}$ Bộ môn Khoa học đất, Khoa Nông nghiệp, Truờng Đại học Cần Tho \\ *Nguoòi chịu trách nhiệm về bài viết: Nguyễn Khởi Nghĩa (email: nknghia@ctu.edu.vn)
}

\section{Thông tin chung:}

Ngày nhận bài: 25/09/2020

Ngày nhận bài sủa: 28/10/2020

Ngày duyệt đăng: 28/04/2021

\section{Title:}

Isolation and selection of plant growth promoting bacteria from plant's leaves

\section{Tù khóa:}

Curtobacterium citreum, Curtobacterium luteum, phân lập, vi khuẩn kích thich sinh trương cây trồng, vi khuẩn lá thưc vật

\section{Keywords:}

Curtobacterium citreum,

Curtobacterium luteum, isolation, leaf-associated bacteria, plant growth promoting bacteria

\begin{abstract}
This study is aimed at isolating and selecting plant growth promoting bacteria associated with plant's leaves. Ammonium Mineral Salt (AMS) was used as a selective medium for bacterial isolation. The seed germination rate, root length, shoot lenght and number of roots were collected to evaluate the effect of bacterial isolates on the growth of maize seeds. The results showed that a total of 28 bacterial strains were isolated from 6 different plant's leaves including Basella rubra L., Rosa chinensis Jacq., Ruellia brittoniana, Arachis pintoi, Ardisia quinquegona Blume, and Coccinia grandis (L) Voigt with a very high diversity in colonical and cell morphologies. Two strains of bacteria denoted as HH5 and MT6 stimulated significantly the seed germination rate and growth of maize as compared to the control treatment (no bacterial inoculation). Additionally, the study also showed that the seed germination rate and growth of maize of treatments inoculated with a bacterial concentration of $10^{6} \mathrm{CFU} . \mathrm{mL}^{-1}$ of these two selected strains were significantly higher than that of the control treatment. Based on 16S-rRNA gene sequences, these two bacterial strains, HH5 and MT6, had a very close genetical relationship with $\underline{\text { Curtobacterium }} \underline{\text { citreum }}$ and $\underline{\text { Curtobacterium }}$ luteum, respectively.
\end{abstract}

\section{TÓM TẮT}

Nghiên cưu thực hiện nhằm phân lập vi khuẩn kich thích sinh truởng cây trồng tù lá thực vật. Môi trường nuôi cấy ammonium mineral salt (AMS) được sủ dụng để phân lập vi khuẩn. Kết quả đã phân lập được 28 dòng vi khuẩn tù lá của 6 loài thực vật khác nhau gồm mồng tơi (Basella rubra L.), hoa hồng (Rosa chinensis Jacq.), chiều tím (Ruellia brittoniana), cỏ đậu (Arachis pintoi), com nguội (Ardisia quinquegona Blume) và bình bát dây (Coccinia grandis (L) Voigt) dựa trên hình thái và màu sắc của khuẩn lạc. Các chỉ tiêu về tỉ lể nảy mầm, chiều dài rễ, chiều cao chồi và số rễ của hạt bắp được khảo sát để đánh giá khả năng kích thích sinh trương của các dòng vi khuẩn phân lập. Các dòng vi khuẩn phân lạp có hình thái khuẩn lạc và tế bào rất đa dạng. Hai dòng vi khuẩn ký hiệu HH5 và MT6 làm gia tăng tỉ lệ nảy mầm và sinh truởng của hạt bắp tốt nhất trong các dòng vi khuẩn phân lập. Bên cạnh đó, nghiên cứu còn cho thấy ở mật số $10^{6} \mathrm{CFU} . \mathrm{mL}^{-1}$ cả hai dòng vi khuẩn giúp gia tăng tỉ lệ nảy mầm và sinh truởng của cây bắp tốt hơn so với mật số $10^{7}$, $10^{8}$ và $10^{9} \mathrm{CFU} . \mathrm{mL}^{-1}$. Kết giải mã trình tụ đoạn gene $16 \mathrm{~S}$ rRNA cho thấy hai dòng vi khuẩn HH5 và MT6 lần luợt có mối quan hệ gần gũi với loài Curtobacterium citreum và Curtobacterium luteum. 


\section{GIỚI THIẸU}

Trong canh tác nông nghiệp, năng suất cây trồng luôn là vấn đề được quan tâm hàng đầu. Do đó, có rất nhiều biện pháp kỹ thuật đã và đang được nghiên cứu và ứng dụng trong canh tác nông nghiệp nhằm cải thiện năng suất, đồng thời tăng cường sức đề kháng của cây trồng đối với mầm bệnh và côn trùng gây hại. Trong đó, biện pháp dùng hóa chất được áp dụng phổ biến nhất trong đó bao gồm việc sử dụng hóa chất, thuốc bảo vệ thực vật (BVTV), phân bón hóa học và hóa chất kích thích sinh trưởng. Thật sự không thể phủ nhận vai trò tích cực của các hóa chất này trong công tác bảo vệ và tăng năng suất cây trồng, tuy nhiên, biện pháp dùng hóa học trong canh tác nông nghiệp dần đến việc ô nhiễm môi trường, suy thoái, bạc màu đất, lưu tồn hóa chất trong môi trường đất, nước, nông sản và ảnh hưởng đến sức khỏe người tiêu dùng (Tổng cục Môi trường, 2015). Do đó, để hạn chế tác tại của hóa chất nông nghiệp lên môi trường, sinh thái, chất lượng nông sản và sức khỏe người tiêu dùng, việc sử dụng các chế phẩm hữu cơ, sinh học và đặc biệt là vi sinh trong canh tác nông nghiệp theo hướng an toàn, sạch và hữu cơ được nghiên cứu và ứng dụng rộng rãi trên thế giới (Trung tâm Thông tin và Thống kê Khoa học và Công nghệ - Sở Khoa học và Công nghệ Thành phố Hồ Chí Minh, 2019).

Các chế phẩm sinh học và vi sinh có chức năng có lợi cho cây trồng như cố định đạm, hòa tan lân, kali, silic,.. tổng hợp các chất hợp chất sinh học như hormone thực vật, vitamins, enzymes giúp kích thích sinh trưởng cây trồng, gây ức chế các mầm bệnh và côn trùng gây hại chủ yếu được phân lập chủ yếu từ đất nông nghiệp. Bên cạnh đất, lá thực vật cũng là một nguồn chứa nhiều nhóm vi sinh vật có lợi cho cây trồng. Trong số đó, nhóm vi khuẩn thuộc chi Methylobacterium và Curtobacterium đã được công bố là có tiềm năng ứng dụng rất lớn. Vi khuẩn Methylobacterium sp. là nhóm vi khuẩn có sắc tố hồng sử dụng dinh dưỡng methyl tuỳ ý (pink pigmented facultative methylotrophic - PPFM) có khả năng sử dụng nhiều hợp chất khác nhau từ một carbon đến nhiều carbon và là vi khuẩn có tiềm năng ứng dụng trong nhiều lĩnh vực khác nhau vì chúng có khả năng sinh tổng hợp các hợp chất thứ cấp có lợi cho thực vật và con người (Urquhart \& Punja, 2002). Chúng hiện diện chủ yếu trên bề mặt thực vật và có ảnh hưởng tích cực tới sự sinh trường và phát triển của thực vật thông qua quá trình tổng hợp các phytohormone (auxin, cytokinin) (Holland, 1997), tiết 1-aminocyclopropane-1-carboxylate deaminase điều hòa ethylen trong cây (Madhaiyan et al., 2006), gia tăng khả năng hấp thu các chất khoáng, gia tăng sự kháng bệnh của thực vật (Maliti, 2000), tổng hợp enzyme urease và cố định nitơ (Sy et al., 2001). Vi khuẩn Methylobacterium sp. có khả năng làm gia tăng năng suất lúa, mía, hạn chế bệnh hại ở cây đậu phộng, cam, chanh và kích thích sinh trưởng của cây thuốc lá, cây hông và cây saintpaulia ở điều kiện phòng thí nghiệm (Araújo et al., 2002). Bên cạnh đó, nhóm vi khuẩn thuộc chi Curtobacterium có mối liên quan mật thiết đến thực vật và đặc biệt là nằm trên bề mặt thực vật (Behrendt et al., 2002; Komagata et al., 1965). Chúng có thể tạo ra các phản ứng khác nhau bằng nhiều cơ chế để bảo vệ cây trồng (Bulgari et al., 2011), giảm thiểu việc xâm nhiễm của tác nhân gây bệnh (Lacava et al., 2007) và thúc đẩy sự sinh trưởng và phát triển của thực vật (Sturz et al., 1997). Dòng vi khuẩn Curtobacterium herbarum đã được chứng minh là có khả năng thúc đẩy sinh trưởng và phát triển ở cây hoa cải, rau diếp, húng quế và cải ngọt (Mayer et al., 2019). Các nghiên cứu về phân lập tuyển chọn và ứng dụng vi khuẩn PPFM giúp kích thích sinh trưởng, tăng năng suất và bảo vệ cây trồng được thực hiện nhiều trên thế giới, tuy nhiên, ở Việt Nam các nghiên cứu về phân lập và ứng dụng các dòng vi khuẩn sống trên lá thực vật nhằm ứng dụng trong canh tác nông nghiệp vẫn còn rất hạn chế. Vì vậy nghiên cứu này được thực hiện với mục tiêu phân lập và tuyển chọn một số dòng vi khuẩn từ lá một số loài thực vật có khả năng kích thích sinh trưởng cây trồng.

\section{PHƯƠNG PHÁP NGHIÊN CÚU}

\subsection{Phân lập vi khuẩn từ lá thực vật có khả năng kích thích sinh trưởng cây trồng}

\subsubsection{Chuẩn bị mẫu lá thực vật}

Tổng cộng 16 mẫu lá thực vật khác nhau dùng làm nguồn vi khuẩn để phân lập vi khuẩn kích thích sinh trưởng cây trồng gồm bắp (Zea mays L.), lúa (Oryza sativa L.), dừa (Cocos nucifera), cải xanh (Brassica juncea (L.) Czern. et Coss), mồng tơi (Basella rubra L.), đậu dại (Pueraria phaseoloides), sa kê (Artocarpus altilis), chiều tím (Ruellia brittoniana), chuối (Musa sapientum), bèo hoa dâu (Azolla Imbriccata), cỏ đậu (Arachis pintoi), đậu xanh (Vigna radiata), bình bát dây (Coccinia grandis (L) Voigt), cơm nguội (Ardisia quinquegona Blume), hoa hồng (Rosa chinensis Jacq.) và cát lồi (Costus speciosus (Koenig) Smith). Cả 16 mẫu lá thực vật này được thu trong khuôn viên Trường Đại Học Cần Thơ. Chọn những lá còn non và đối với những lá có kích thước lớn, sau khi thu xong tiến hành cắt thành những mảnh nhỏ để vừa với kích thước của đĩa petri. 


\subsubsection{Bố trí thí nghiệm}

Mẫu lá thực vật sau khi thu thập được rửa sạch bụi dưới vòi nước và rửa lại với nước khử khoáng tiệt trùng, để ráo, sau đó dùng nhíp đặt lá và ấn mạnh lá lên trên bề mặt đĩa môi trường $\mathrm{AMS}$ để tạo nên vết lá hiện lên trên bề mặt môi trường nuôi cấy agar và sau đó lá được lấy ra khỏi đĩa petri (Holland et al., 2000). Thành phần của $1 \mathrm{~L}$ môi trường $\mathrm{AMS}$ như sau (g/L) $\mathrm{K}_{2} \mathrm{HPO}_{4} .3 \mathrm{H}_{2} \mathrm{O} \quad 0.94 \mathrm{~g}, \mathrm{KH}_{2} \mathrm{PO}_{4} 0.54 \mathrm{~g}$, $\mathrm{MgSO}_{4} .7 \mathrm{H}_{2} \mathrm{O} 1 \mathrm{~g}, \mathrm{CaCl}_{2} .1 \mathrm{H}_{2} \mathrm{O} 0.2 \mathrm{~g}, \mathrm{NH}_{4} \mathrm{Cl} 0.5 \mathrm{~g}$, $\mathrm{FeSO}_{4} .7 \mathrm{H}_{2} \mathrm{O} 0.4 \mathrm{~g}, \mathrm{ZnSO}_{4} .7 \mathrm{H}_{2} \mathrm{O} 0.1 \mathrm{~g}, \mathrm{MnCl}_{2} .4 \mathrm{H}_{2} \mathrm{O}$ $0.03 \mathrm{~g}, \mathrm{H}_{3} \mathrm{PO}_{4} 0.3 \mathrm{~g}, \mathrm{CoCl}_{2} .6 \mathrm{H}_{2} \mathrm{O}, \mathrm{Na}_{2} \mathrm{MoO}_{4} .2 \mathrm{H}_{2} \mathrm{O}$ $0.06 \mathrm{~g}, \mathrm{NiCl}_{2} .6 \mathrm{H}_{2} \mathrm{O} 0.02 \mathrm{~g}, 5 \mathrm{~mL}$ Methanol và agar $15 \mathrm{~g}$ trong $1 \mathrm{~L}$ nước khử khoáng (Holland et al., 2000). Môi trường được khử trùng ở $121^{\circ} \mathrm{C}$ kéo dài 20 phút dưới $1 \mathrm{~atm}$ trong nồi hấp tiệt trùng. Đặt đĩa petri chứa vi khuẩn trong tối trong 5 ngày ở nhiệt độ phòng thí nghiệm. Quan sát sự phát triển của khuẩn lạc, đến khi khuẩn lạc vi khuẩn màu hồng phát triển tốt. Tiến hành thu sinh khối của toàn bộ vi khuẩn phát triển trên bề mặt môi trường nuôi cấy agar bằng cách hút $5 \mathrm{~mL}$ nước khử khoáng tiệt trùng cho vào bề mặt đĩa petri, dùng que chà, chà nhẹ trên bề mặt agar để sinh khối vi khuẩn hòa tan vào nước. Tiến hành thu dịch huyền phù vi khuẩn này và cho vào bình tam giác $250 \mathrm{~mL}$ chứa $45 \mathrm{~mL}$ môi trường $\mathrm{AMS}$ lỏng và được nuôi trên máy lắc tròn với tốc độ 100 vòng/phút cho đến khi sinh khối phát triển tốt thông qua việc quan sát độ đục và tạo màu hồng của môi trường nuôi cấy. Tiểp theo, tiến hành hút $5 \mathrm{~mL}$ môi trường nuôi cấy chứa vi khuẩn này cho vào bình tam giác mới chứa $45 \mathrm{~mL}$ môi trường $\mathrm{AMS}$ lỏng và tiến hành lặp lại quy trình nhân nuôi sinh khối nhóm vi khuẩn trong 5 thế hệ liên tục.

\subsubsection{Khảo sát khả năng kích thích tỉ lệ nảy mầm hạt bắp của 16 hệ vi khuẩn tù lá thực vật khác nhau sau khi nhân sinh khối}

Ở thế hệ thứ 5 sau khi môi trường cấy xuất hiện độ đục cao và tạo màu hồng tốt, tiến hành thu sinh khối vi khuẩn bằng cách chuyển toàn bộ dịch huyền phù vi khuẩn nuôi cấy cho vào Falcon $50 \mathrm{~mL}$ tiệt trùng và $l y$ tâm ở tốc độ 6.000 vòng/phút trong 5 phút. Sau đó, loại bỏ phần nước nằm bên trên và cho $50 \mathrm{~mL}$ nước cất tiệt trùng vào, vortex đều mẫu, sau đó xác định mật số vi khuẩn của mỗi hệ vi khuẩn bằng phương pháp nhỏ giọt (Miles et al., 1938) và hiệu chỉnh mật số vi khuẩn của mỗi hệ vi khuẩn về nồng độ $10^{6} \mathrm{CFU} \cdot \mathrm{mL}^{-1}$. Hạt giống bắp được tiệt trùng trước bằng dung dịch $\mathrm{NaClO} 1 \%$ trong 10 phút và cồn $70 \%$ trong 1 phút và được rửa sạch 4 lần với nước cất tiệt trùng. Tiếp theo, cho 10 hạt giống bắp đã tiệt trùng xong vào ống Falcon $50 \mathrm{~mL}$ tiệt trùng chứa $20 \mathrm{~mL}$ dung dịch huyền phù vi khuẩn với mật số $10^{6} \mathrm{CFU} \cdot \mathrm{mL}^{-1}$ và ngâm trong 16 giờ. Mỗi Falcon chứa vi khuẩn tương ứng với 1 lặp lại và thí nghiệm được bố trí với 3 lặp lại cho mỗi hệ vi khuẩn lá khác nhau. Sau đó, tiến hành đặt các hạt bắp lên đĩa petri đặt sẵn giấy lọc tiệt trùng có bổ sung $10 \mathrm{~mL}$ nước cất tiệt trùng để tạo ẩm độ cho hạt nảy mầm và các đĩa petri chứa hạt được đặt trong tối trong 4 ngày. Nghiệm thức đối chứng được thực hiện tương tự nhưng không chủng vi khuẩn vào trong hạt bắp. Tiến hành theo dõi chỉ tiêu tỉ lệ nảy mầm của hạt bắp sau 2 ngày thí nghiệm.

2.1.4. Tách ròng và tinh sạch các dòng vi khuẩn có khả năng kích thich sinh truơong cây trồng tù̀ các dòng vi khuẩn thể hiện khả năng kich thich sinh trương cây bắp tốt nhất

Dựa vào kết quả khảo sát khả năng kích thích sinh trưởng của 16 hệ vi khuẩn phân lập từ 16 mẫu lá thực vật khác nhau ở mục 2.1 .3 chọn ra các hệ vi khuẩn có khả năng kích thích sinh trưởng cây bắp tốt nhất để tách ròng và tinh sạch các dòng vi khuẩn. Quy trình được thực hiện như sau: Hút $1 \mathrm{~mL}$ mẫu dịch huyền phù vi khuẩn của các hệ vi khuẩn này ở thế hệ thứ 5 pha loãng thành các dãy nồng độ khác nhau theo hệ số pha loãng 10 . Sau đó hút $50 \mu \mathrm{L}$ dung dịch huyền phù vi khuẩn ở các nồng độ pha loãng này và trải lên trên đĩa môi trường khoáng $\mathrm{AMS}$ agar bằng que chà. Các đĩa petri chứa mẫu được trữ ở điều kiện phòng thí nghiệm và trong tối trong 5 ngày. Quan sát khuẩn lạc phát triển trên môi trường nuôi cấy và tiến hành chọn các khuẩn lạc rời có hình thái và màu sắc khuẩn lạc khác nhau để cấy chuyển liên tục 4-5 lần trên môi trường AMS agar để thu được các dòng vi khuẩn thuần. Các dòng vi khuẩn phân lập được mô tả hình thái khuẩn lạc và tế bào cũng như nhuộm Gram vi khuẩn. Đồng thời, khuẩn lạc của các dòng vi khuẩn này được trữ trong glycerol $30 \%$ ở - $30^{\circ} \mathrm{C}$ cho các thí nghiệm tiếp theo.

\subsection{Khảo sát và đánh giá khả năng kích thích sinh trưởng cây bắp của các dòng vi khuẩn phân lập}

\subsubsection{Chuẩn bị nguồn vi khuẩn}

Cho 1 khuẩn lạc vi khuẩn của các dòng vi khuẩn thử nghiệm vào trong bình tam giác $100 \mathrm{~mL}$ chứa 30 $\mathrm{mL}$ AMS lỏng tiệt trùng để nhân mật số. Các bình tam giác chứa vi khuẩn được đặt trên máy lắc tròn với tốc độ 90 vòng/phút trong 2 ngày và trong tối. Tiến hành thu sinh khối vi khuẩn bằng cách chuyển toàn bộ dịch huyền phù vi khuẩn nuôi cấy cho vào Falcon $50 \mathrm{~mL}$ tiệt trùng và ly tâm ở tốc độ 6000 vòng/phút trong 5 phút. Sau đó, xác định mật số vi 
khuẩn bằng phương pháp nhỏ giọt (Miles et al., 1938 ) và hiệu chỉnh về mật số $10^{6}$ CFU.mL ${ }^{-1}$.

\subsubsection{Bố trí thí nghiệm}

Thí nghiệm được bố trí tương tự như mục 2.1.3 nhưng các hệ vi khuẩn được thay bằng các dòng vi khuẩn. Mỗi dòng vi khuẩn là một nghiệm thức được thực hiện với 3 lần lặp lại và mỗi lặp lại có 10 hạt bắp. Nghiệm thức chủng nước cất tiệt trùng không chứa vi khuẩn vào trong hạt bắp được $\mathrm{xem}$ như là nghiệm thức đối chứng. Thí nghiệm được kéo dài trong 4 ngày và các chỉ tiêu theo dõi cũng tương tự như mục 2.1.3.

2.3. Khảo sát và đánh giá ảnh hưởng của các mật số vi khuẩn khác nhau của hai dòng vi khuẩn tuyển chọn lên tỉ lệ nảy mầm hạt bắp ở điều kiện phòng thí nghiệm

\subsubsection{Chuẩn bị nguồn vi khuẩn}

Việc chuẩn bị nguồn vi khuẩn của hai dòng vi khuẩn tuyển chọn được thực hiện như mục 2.2 .1 và mật số của mỗi dòng vi khuẩn được hiệu chỉnh về 4 nồng độ gồm $10^{6}, 10^{7}, 10^{8}$ và $10^{9} \mathrm{CFU} \cdot \mathrm{mL}^{-1}$.

\subsubsection{Bố trí thí nghiệm}

Thí nghiệm được bố trí tương tự như mục 2.2.2. Nghiệm thức chủng nước cất tiệt trùng không chứa vi khuẩn vào trong hạt bắp được xem như là nghiệm thức đối chứng. Thí nghiệm được bố trí với 5 nghiệm thức trong đó có 1 nghiệm thức đối chứng và 4 nghiệm thức chứa 4 mật số vi khuẩn khác nhau gồm $10^{6}, 10^{7}, 10^{8}$ và $10^{9} \mathrm{CFU} \cdot \mathrm{mL}^{-1}$. Mỗi nghiệm thức được thực hiện với 3 lần lặp lại và mỗi lặp lại có 10 hạt bắp. Thí nghiệm được kéo dài trong 4 ngày và xác định chỉ tiêu về tỉ lệ nảy mầm của hạt bắp.

\section{4. Định danh hai dòng vi khuẩn tuyển chọn thể hiện khả năng kích thích sinh trưởng cây trồng tốt nhất bằng phương pháp giải trình tự đoạn gene $16 \mathrm{~S}$ rRNA}

DNA của hai dòng vi khuẩn tuyển chọn có khả năng kích thích sinh trưởng cây trồng tốt nhất được tách chiết bằng phương pháp sử dụng $\mathrm{CTAB} 3 \%$ theo quy trình của Ihrmark et al. (2012). DNA của hai dòng vi khuẩn được khuếch đại gene $16 \mathrm{~S}$-rRNA với cặp mồi được sử dụng là: $27 \mathrm{~F}$ (5'- AGA GTT TGA TCC TGG CTC-3'), 1492R (5'- TAC GGT TAC CTT GTT ACG ACT -3') (Weisburg et al., 1991). Các bước trong phản ứng PCR như sau: bước 1: $94^{\circ} \mathrm{C}$ trong 5 phút; bước $2: 94^{\circ} \mathrm{C}$ trong 1 phút: bước 3: $55^{\circ} \mathrm{C}$ trong 1 phút; bước $4: 72^{\circ} \mathrm{C}$ trong 2 phút; bước 5: lặp lại bước 2 thêm 34 chu kỳ; bước 6: $72^{\circ} \mathrm{C}$ trong 7 phút và bước $7: 4^{\circ} \mathrm{C}$ trong thời gian không xác định. Thành phần của một phản ứng PCR với tổng thể tích $25 \mu \mathrm{L}$ như sau: $12,5 \mu \mathrm{L}$ Go Taq Green Master Mix, $0,5 \mu \mathrm{L}$ mồi xuôi $(10 \mu \mathrm{M}), 0,5 \mu \mathrm{L}$ mồi ngược $(10 \mu \mathrm{M}), 10,5 \mu \mathrm{L}$ nước không chứa DNA và $1 \mu \mathrm{L}$ DNA tinh sạch. Kết quả giải trình tự được so sánh và dò tìm trên ngân hàng gene thế giới trên trang web http://blast.ncbi.nlm.nih.gov/Blast.cgi để định danh khoa học hai dòng vi khuẩn tuyển chọn.

\subsection{Xử lý số liệu}

Số liệu được tổng hợp và xử lí bằng phần mềm Excel và được kiểm định thống kê bằng phần mềm Minitab 16.2 theo phương pháp kiểm định Tukey ở mức ý nghĩa 5\%.

\section{KẾT QUẢ VÀ THẢO LUẬN}

\subsection{Phân lập vi khuẩn từ lá thực vật có khả năng kích thích sinh trưởng cây trồng}

Từ 16 mẫu lá thực vật thu thập đã ly trích được 16 hệ vi khuẩn trên lá khác nhau và sau 5 thế hệ nhân sinh khối vi khuẩn liên tục trong môi trường AMS lỏng tiến hành kiểm tra khả năng kích thích sinh trưởng cây bắp của 16 hệ vi khuẩn này để làm nền tảng cho việc chọn lựa các hệ vi khuẩn có khả năng kích thích sinh trưởng cây trồng để tiến hành phân lập các dòng vi khuẩn đơn. Kết quả khảo sát khả năng kích thích sinh trưởng cây trông của 16 hệ vi khuẩn sau 4 ngày thí nghiệm được trình bày ở Hình 1.

Kết quả cho thấy tỉ lệ nảy mầm của hạt bắp sau 2 ngày thí nghiệm hầu hết ở tất cả các nghiệm thức chủng với 16 hệ vi khuẩn phân lập từ 16 mẫu lá thực vật (trừ nghiệm thức chủng với hệ vi khuẩn từ lá cải xanh và lá dừa) cao hơn khác biệt ý nghĩa thống kê so với nghiệm thức đối chứng không chủng vi khuẩn $(\mathrm{p}<0,05)$. Trong đó nghiệm thức chủng hệ vi khuẩn từ lá cây hoa hồng cho tỉ lệ nảy mầm cao nhất, đạt $80 \%$ và khác biệt ý nghĩa thống kê $(\mathrm{p}<0,05)$ khi so với các nghiệm thức còn lại. Các nghiệm thức chủng hệ vi khuẩn từ lá cây chiều tím, bình bát dây, cơm nguội, cỏ đậu và mồng tơi có tỉ lệ nảy mầm hạt bắp dao động trong khoảng từ 73,3\% - 76,7\%, khác biệt không ý nghĩa thống kê $(\mathrm{p}>0,05)$ khi so sánh với nhau nhưng khác biệt ý nghĩa thống kê với các nghiệm thức còn lại $(\mathrm{p}<0,05)$. Nghiệm thức đối chứng có tỉ lệ nảy mầm thấp nhất $(53,3 \%)$. Như vậy, kết quả này cho thấy việc chủng các hệ vi khuẩn từ lá thực vật giúp gia tăng tỉ lệ nảy mầm của hạt bắp và theo nghiên cứu của Holland and Polacco (1994) về nhóm vi khuẩn Methylobacterium cho thấy rằng, nếu loại bỏ vi khuẩn nội sinh ở hạt dẫn đến tỉ lệ nảy mầm hạt giảm xuống, tuy nhiên khi chủng vi khuẩn trong nhóm Methylobacterium giúp phục hồi và tăng cường tỉ lệ nảy mầm của hạt. Dựa vào kết quả 
này, tiến hành chọn 6 hệ vi khuẩn từ lá hoa hồng, bình bát dây, cơm nguội, cỏ đậu, chiều tím và mồng tơi để tiến hành phân lập các dòng vi khuẩn có khả năng kích thích sinh trưởng cây trồng.

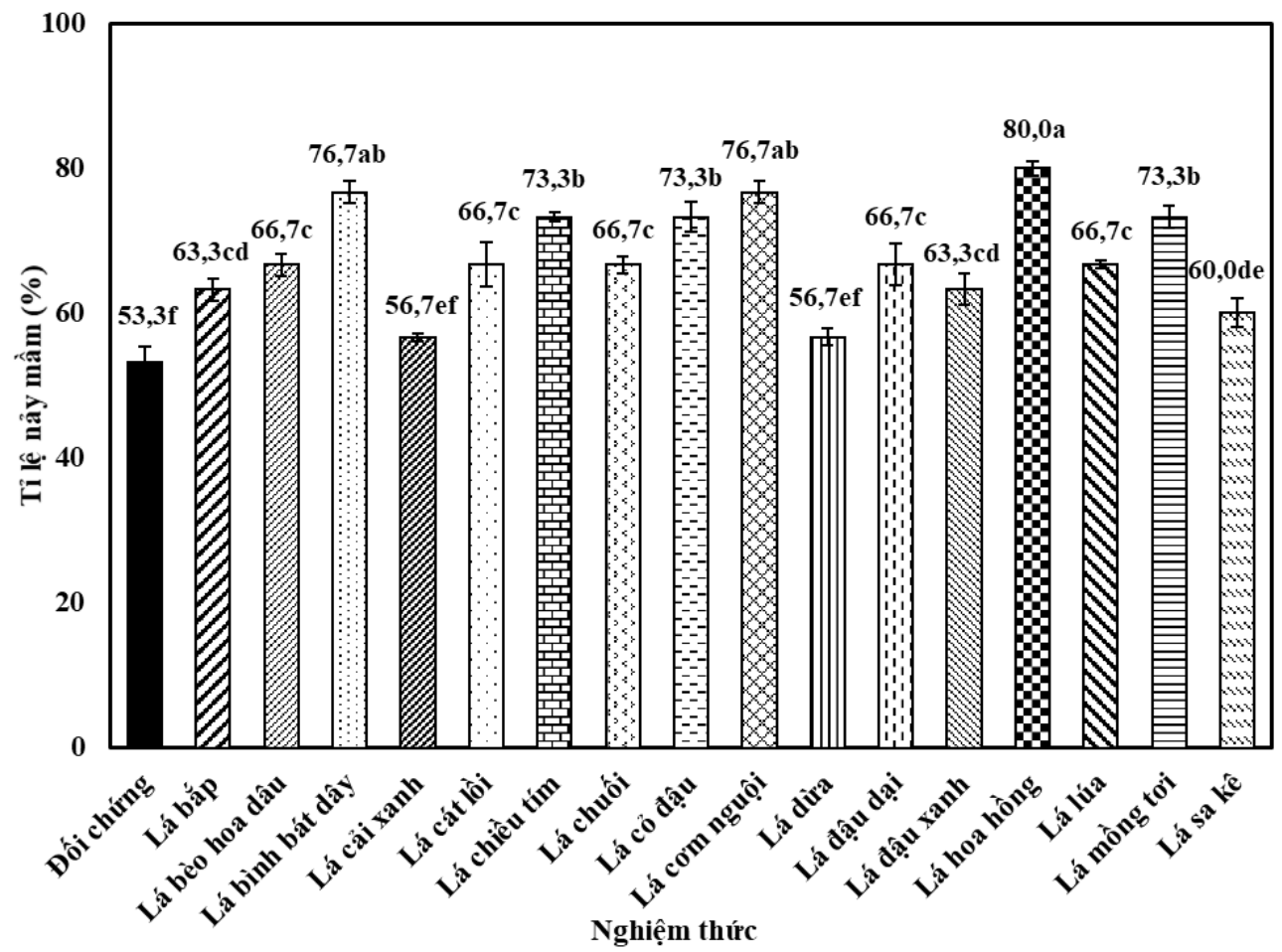

Hình 1. Tỉ lệ nảy mầm của hạt bắp của các nghiệm thức chủng 16 hệ vi khuẩn từ lá thực vật (n=3)

Ghi chú: Nhũng số có chũ theo sau khác nhau thì có khác biệt ý nghĩa thống kể ở mức ý nghĩa 5\%

Bảng 1. Đặc điểm hình thái khuẩn lạc, tế bào và gram của 28 dòng vi khuẩn phân lập từ 6 hệ vi khuẩn lá thực vật có khả năng kích thích sinh trưởng cây trồng tốt nhất

\begin{tabular}{|c|c|c|c|}
\hline Chỉ tiêu & Đặc điểm & Số lượng (dòng) & Tỉ lệ (\%) \\
\hline \multirow{2}{*}{ Hình dạng khuẩn lạc } & Tròn & 21 & 75,0 \\
\hline & Không tròn & 7 & 25,0 \\
\hline \multirow{2}{*}{ Độ nhô của khuẩn lạc } & Nhô & 5 & 17,9 \\
\hline & Không nhô & 23 & 82,1 \\
\hline \multirow{4}{*}{ Màu sắc khuẩn lạc } & Trắng & 1 & 3,6 \\
\hline & Trắng đục & 15 & 53,6 \\
\hline & Vàng & 10 & 35,7 \\
\hline & Hồng & 2 & 7,1 \\
\hline \multirow{2}{*}{ Bề mặt khuẩn lạc } & Có nếp nhăn & 6 & 21,4 \\
\hline & Trơn bóng & 22 & 78,6 \\
\hline \multirow{3}{*}{ Dạng viền của khuẩn lạc } & Nguyên & 19 & 67,9 \\
\hline & Gợn sóng & 7 & 25,0 \\
\hline & Chia thùy & 2 & 7,1 \\
\hline \multirow{2}{*}{ Sa cấu bề mặt khuẩn lạc } & Khô & 18 & 64,3 \\
\hline & Ầm & 10 & 35,7 \\
\hline \multirow{2}{*}{ Hình dạng tế bào } & Que ngắn & 21 & 75,0 \\
\hline & Cầu & 7 & 25,0 \\
\hline \multirow{2}{*}{ Gram } & - & 2 & 7,1 \\
\hline & + & 26 & 92,9 \\
\hline
\end{tabular}


Kết quả phân lập vi khuẩn có khả năng kích thích sinh trưởng cây trồng từ 6 hệ vi khuẩn từ lá của 6 loại thực vật khác nhau gồm hoa hồng, bình bát dây, cơm nguội, cỏ đậu, chiều tím và mồng tơi cho thấy tổng cộng có 28 dòng vi khuẩn được phân lập dựa vào hình thái và màu sắc khuẩn lạc vi khuẩn, trong đó có 6 dòng vi khuẩn được phân lập từ hệ vi khuẩn lá hoa hồng và được ký hiệu từ HH1 - HH6, 4 dòng vi khuẩn được phân lập từ hệ vi khuẩn lá bình bát dây và được ký hiệu từ BBD1 - BBD4, 4 dòng vi khuẩn được phân lập từ hệ vi khuẩn lá cơm nguội và được ký hiệu từ $\mathrm{CN} 1$ - CN4, 6 dòng vi khuẩn được
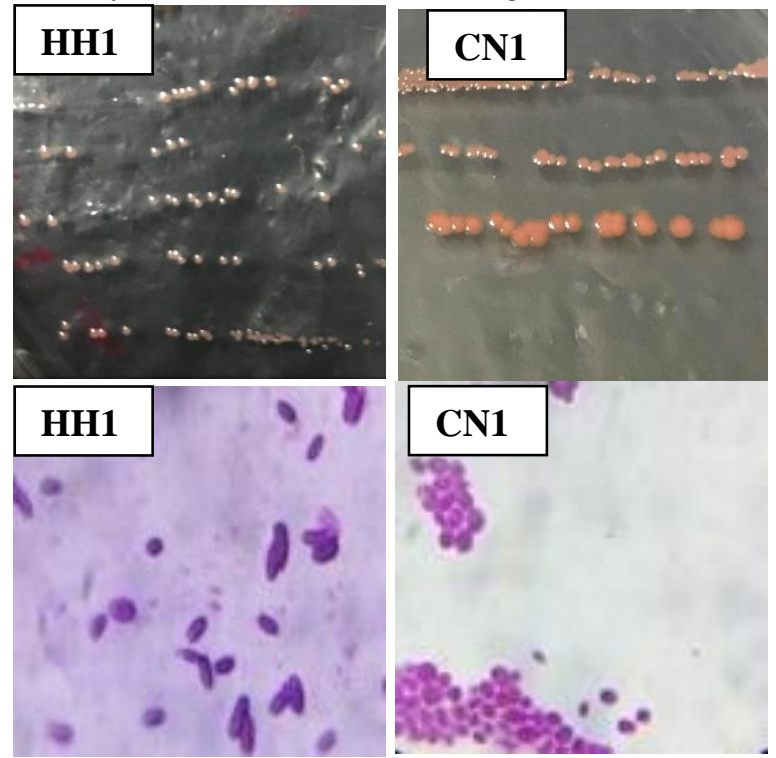

Hình 2. Hình thái khuẩn lạc và tế bào của một số dòng vi khuẩn phân lập tiêu biểu

\subsection{Khảo sát và đánh giá khả năng kích thích sinh trưởng cây bắp của các dòng vi khuẩn phân lập}

Kết quả khảo sát khả năng kích thích sinh trưởng cây bắp của 28 dòng vi khuẩn phân lập sau 4 ngày thí nghiệm được trình bày trong Bảng 2 . Kết quả cho thấy tỉ lệ nảy mầm của hạt bắp ở các nghiệm thức là khác nhau. Trong đó, nghiệm thức đối chứng không chủng vi khuẩn có tỉ lệ nảy mầm đạt $53,3 \%$. Các nghiệm thức chủng với dòng vi khuẩn ký hiệu BBD1, BBD2, BBD3, BBD4, CĐ1, CĐ2, CĐ5, CN3, CT, HH1, HH4, HH6, MT1, MT2, MT4, MT5, MT7 có tỉ lệ nảy mầm hạt bắp tương đương và khác biệt không ý nghĩa thống kê khi so sánh với nghiệm thức đối chứng không chủng vi khuẩn. Kết quả này cho thấy các dòng vi khuẩn này không giúp kích thích gia tăng cũng không làm ức chế tỉ lệ này mầm của hạt bắp. Bên cạnh đó, các nghiệm thức chủng dòng vi khuẩn ký hiệu $\mathrm{CĐ6}, \mathrm{CN} 2, \mathrm{CN} 4$ và HH3 có tỉ lệ nảy mầm thấp hơn, khác biệt ý nghĩa phân lập từ hệ vi khuẩn lá cỏ đậu và được ký hiệu từ CĐ1 - CĐ6, 1 dòng vi khuẩn được phân lập từ hệ vi khuẩn lá chiều tím và được ký hiệu là $\mathrm{CT}$ và 7 dòng vi khuẩn được phân lập từ hệ vi khuẩn lá mồng tơi và được ký hiệu từ MT1 - MT7. Kết quả mô tả đặc điểm hình thái khuẩn lạc, tế bào và gram của 28 dòng vi khuẩn phân lập được trình bày trong Bảng 1 và Hình 2 . Kết quả cho thấy đa số các dòng vi khuẩn là Gram dương, hình que ngắn, khuẩn lạc tròn, bóng và màu sắc khuẩn lạc từ trắng, trắng đục, vàng và hồng. Khuẩn lạc của vi khuẩn sau 2 ngày có kích thước dao động 0,1-0,8 mm (Hình 2).

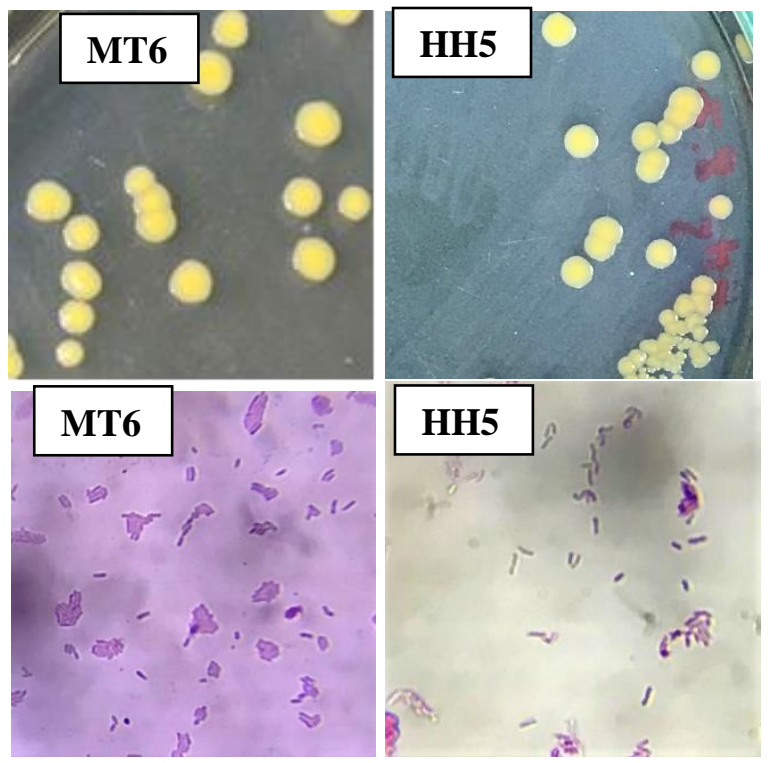

thống kê $(p<0,05)$ so với nghiệm thức đối chứng, không chủng vi khuẩn và đạt $43,3 \%$. Điều này cho thấy các dòng vi khuẩn này đã ức chế sự nảy mầm của hạt bắp. Trong khi đó các nghiệm thức chủng các dòng vi khuẩn ký hiệu $\mathrm{CĐ} 3, \mathrm{C}$ 4, CN1, HH1, HH5, MT3 và MT6 có tỉ lệ nảy mầm hạt bắp cao hơn, khác biệt ý nghĩa thống kê $(\mathrm{p}<0,05)$ khi so sánh với nghiệm thức đối chứng và dao động trong khoảng từ $63,3 \%-73,3 \%$. Trong số các dòng vi khuẩn kích thích tỉ lệ nảy mầm hạt bắp, hai nghiệm thức chủng hai dòng vi khuẩn ký hiệu $\mathrm{HH} 5$ và MT6 có tỉ lệ nảy mầm hạt bắp cao nhất, đều đạt $73,3 \%$ và khác biệt ý nghĩa thống kê $(\mathrm{p}<0,05)$ so với tất cả các nghiệm thức còn lại. Kết quả này phù hợp với kết quả nghiên cứu của Kiều Phương Nam (2010) cho thấy các dòng vi khuẩn phân lập Methylobacterium spp. từ lá cây có chức năng kích thích sự nảy mầm hạt đối với cây đậu đũa, đậu xanh, lúa và bắp. Ngoài ra, các chỉ tiêu sinh trưởng khác như chiều dài rễ chính, số rễ và chiều cao chồi cũng có kết quả tương tự như chỉ tiêu về tỉ lệ nảy mầm hạt bắp. Có nghĩa là 
một số dòng vi khuẩn thử nghiệm không có chức năng kích thích gia tăng cũng không ức chế các chỉ tiêu sinh trưởng này. Trong khi một số dòng vi khuẩn thử nghiệm có chức năng ức chế sự phát triển về các chỉ tiêu sinh trưởng này và cuối cùng có một số dòng vi khuẩn thử nghiệm có chức năng kích thích làm gia tăng các chỉ tiêu sinh trưởng này. Trong đó, đặc biệt một lần nữa hai nghiệm thức chủng 2 dòng vi khuẩn thử nghiệm ký hiệu HH5 và MT6 có chiều dài rễ chính, số rễ và chiều cao chồi cao hơn và khác biệt ý nghĩa thống kê $(\mathrm{p}<0,05)$ so với các nghiệm thức còn lại. Kết quả nghiên cứu của Kiều Phương Nam (2009) cho thấy dòng vi khuẩn Methylobacterium radiotolerans 1019 phân lập từ lá cây giúp gia tăng khả năng tạo chồi từ mô lá của cây cà chua và thuốc lá trên môi trường Mineral Salt có bổ sung cytokinin trong điều kiện nuôi cấy in vitro. Nghiên cứu này cũng cho thấy vi khuẩn $M$. radiotolerans 1019 có tác động kích thích sự phát triển của rễ cây hoa cúc. Trên môi trường cảm ứng tạo rễ, việc bổ sung dòng vi khuẩn này có tác dụng rút ngắn thời gian hình thành rễ, số rễ nhiều hơn và chiều dài rễ dài hơn so với nghiệm thức đối chứng không chủng vi khuẩn. Kết quả này cho thấy 2 dòng vi khuẩn ký hiệu $\mathrm{HH} 5$ và MT6 có thể được xem như là hai dòng vi khuẩn phân lập có khả năng kích thích sinh trưởng hạt bắp tốt nhất và được chọn để thực hiện các nghiên cứu kế tiếp.

Bảng 2. Ảnh hưởng của việc chủng 28 dòng vi khuẩn phân lập lên sinh trưởng cây bắp ở điều kiện phòng thí nghiệm $(\mathrm{n}=3)$

\begin{tabular}{|c|c|c|c|c|c|}
\hline STT & Nghiệm thức & $\begin{array}{r}\text { Tỉ lệ nảy mầm } \\
(\%)\end{array}$ & $\begin{array}{r}\text { Chiều dài rễ chính } \\
(\mathrm{cm})\end{array}$ & $\begin{array}{r}\text { Chiều cao chồi } \\
(\mathrm{cm})\end{array}$ & $\begin{array}{r}\text { Số rễ̂ } \\
\text { (rễ) }\end{array}$ \\
\hline 1 & Đối chứng & $53,3^{\text {cde }}$ & $3,2^{\mathrm{ik}}$ & $1,7^{\mathrm{hi}}$ & $4,2^{\text {defg }}$ \\
\hline 2 & BBD1 & $53,3^{\text {cde }}$ & $4,5^{\mathrm{bc}}$ & $1,4^{\mathrm{hi}}$ & $3,8^{\text {hij }}$ \\
\hline 3 & BBD2 & $50,0^{\text {def }}$ & $4,3^{\text {bcde }}$ & $1,6^{\text {fgh }}$ & $4,2^{\text {defg }}$ \\
\hline 4 & BBD3 & $60.0^{\mathrm{bcd}}$ & $4,3^{\text {bcde }}$ & $1,5^{\mathrm{gh}}$ & $4,3^{\mathrm{def}}$ \\
\hline 5 & BBD4 & $53,3^{\text {cde }}$ & $4,7^{\mathrm{ab}}$ & $1,8^{\text {abcde }}$ & $4,8^{\mathrm{bc}}$ \\
\hline 6 & $\mathrm{CĐ1}$ & $56,7^{\text {bcd }}$ & $3,7^{\text {ghij }}$ & $1,9^{\mathrm{abcd}}$ & $4,2^{\text {defg }}$ \\
\hline 7 & $\mathrm{C} Ð 2$ & $60,0^{\text {cde }}$ & $3,2^{\mathrm{k}}$ & $1,8^{\text {bcdef }}$ & $4,2^{\text {defg }}$ \\
\hline 8 & $\mathrm{C} \bigoplus 3$ & $63,3^{\mathrm{b}}$ & $3,2^{\mathrm{jk}}$ & $1,9^{\mathrm{abcd}}$ & $3,7^{\mathrm{ijk}}$ \\
\hline 9 & $\mathrm{C}$ 4 & $63,3^{\mathrm{b}}$ & $3,6^{\mathrm{hijk}}$ & $1,7^{\text {bcdefg }}$ & $4,4^{\text {cdef }}$ \\
\hline 10 & $\mathrm{C} Đ 5$ & $46,7^{\mathrm{ef}}$ & $3,2^{\mathrm{jk}}$ & $1,7^{\text {defg }}$ & $4,1^{\text {fgh }}$ \\
\hline 11 & $\mathrm{CĐ6}$ & $43,3^{\mathrm{f}}$ & $3,7^{\text {hijk }}$ & $1,7^{\text {defg }}$ & $3,5^{\mathrm{jk}}$ \\
\hline 12 & CN1 & $63,3^{\mathrm{b}}$ & $4,7^{\mathrm{ab}}$ & $1,9^{\mathrm{abc}}$ & $4,9^{\mathrm{ab}}$ \\
\hline 13 & $\mathrm{CN} 2$ & $43,3^{\mathrm{f}}$ & $3,9^{\mathrm{ijk}}$ & $1,9^{\mathrm{abcd}}$ & $3,9^{\text {ghi }}$ \\
\hline 14 & $\mathrm{CN} 3$ & $53,3^{\text {cde }}$ & $3,9^{\text {efghi }}$ & $1,1^{\mathrm{jk}}$ & $4,3^{\mathrm{def}}$ \\
\hline 15 & $\mathrm{CN} 4$ & $43,3^{\mathrm{f}}$ & $4,2^{\text {cdefg }}$ & $1,4^{\mathrm{hi}}$ & $4,3^{\mathrm{def}}$ \\
\hline 16 & $\mathrm{CT}$ & $46,7^{\mathrm{ef}}$ & $4,2^{\text {cdefg }}$ & $1,2^{\mathrm{ij}}$ & $4,4^{\mathrm{def}}$ \\
\hline 17 & HH1 & $63,3^{\mathrm{b}}$ & $4,0^{\text {cdefgh }}$ & $1,2^{\mathrm{ij}}$ & $4,4^{\mathrm{def}}$ \\
\hline 18 & HH2 & $60,0^{\mathrm{bc}}$ & $4,2^{\text {cdef }}$ & $1,2^{\mathrm{ij}}$ & $4,4^{\mathrm{def}}$ \\
\hline 19 & HH3 & $43,3^{\mathrm{f}}$ & $3,8^{\text {fghi }}$ & $1,1^{\mathrm{jk}}$ & $4,5^{\mathrm{cde}}$ \\
\hline 20 & HH4 & $46,7^{\mathrm{ef}}$ & $3,5^{\mathrm{ijk}}$ & $0,8^{1}$ & $3,4^{\mathrm{k}}$ \\
\hline 21 & HH5 & $73,3^{\mathrm{a}}$ & $5,1^{\mathrm{a}}$ & $2,1^{\mathrm{a}}$ & $5,2^{\mathrm{a}}$ \\
\hline 22 & HH6 & $56,7^{\text {bcd }}$ & $3,7^{\text {fghi }}$ & $0,9^{\mathrm{kl}}$ & $4,5^{\mathrm{cd}}$ \\
\hline 23 & MT1 & $60,0^{\mathrm{bc}}$ & $4,4^{\mathrm{bcd}}$ & $1,1^{\mathrm{jk}}$ & $4,2^{\operatorname{defg}}$ \\
\hline 24 & MT2 & $56,7^{\text {bcd }}$ & $3,2^{\mathrm{jk}}$ & $0,7^{1}$ & $3,7^{\text {hijk }}$ \\
\hline 25 & MT3 & $63,3^{\mathrm{b}}$ & $3,9^{\text {efghi }}$ & $1,3^{\mathrm{ij}}$ & $4,4^{\text {def }}$ \\
\hline 26 & MT4 & $53,3^{\text {cde }}$ & $3,6^{\mathrm{hijk}}$ & $0,8^{1}$ & $3,7^{\text {hijk }}$ \\
\hline 27 & MT5 & $50,0^{\text {def }}$ & $3,5^{\mathrm{ijk}}$ & $1,6^{\mathrm{ij}}$ & $4,1^{\text {efgh }}$ \\
\hline 28 & MT6 & $73,3^{\mathrm{a}}$ & $5,1^{\mathrm{a}}$ & $2,0^{\mathrm{ab}}$ & $5,2^{\mathrm{a}}$ \\
\hline 29 & MT7 & $50,0^{\text {def }}$ & $3,8^{\text {fghi }}$ & $1,8^{\text {bcde }}$ & $4,1^{\text {efgh }}$ \\
\hline \multicolumn{2}{|c|}{$\mathrm{CV}(\%)$} & 17,5 & 15,5 & 7,1 & 11,4 \\
\hline \multicolumn{2}{|c|}{$\mathrm{F}^{*}$} & * & * & * & * \\
\hline
\end{tabular}

Ghi chú: *: khác biệt thống kê ở mức ý nghĩa 5\%; Trong cùng một cột, nhũng số có chũ theo sau khác nhau thì có khác biệt ý nghĩa thống kê ở mức 5\% 


\section{3. Ảnh hưởng của các mật số vi khuẩn khác nhau của hai dòng vi khuẩn tuyển chọn HH5 và MT6 lên tỉ lệ nảy mầm của hạt bắp ở điều kiện phòng thí nghiệm}

Kết quả khảo sát ảnh hưởng của các mật số vi khuẩn khác nhau của hai dòng vi khuẩn tuyển chọn HH5 và MT6 lên tỉ lệ nảy mầm hạt bắp được trình bày ở Hình 3.

Kết quả cho thấy việc chủng 2 dòng vi khuẩn $\mathrm{HH} 5$ và MT6 ở nồng độ $10^{6} \mathrm{CFU} \cdot \mathrm{mL}^{-1}$ giúp gia tăng tỉ lệ nảy mầm của hạt bắp. Đối với dòng vi khuẩn HH5, nghiệm thức chủng mật số $10^{6} \mathrm{CFU} \cdot \mathrm{mL}^{-1}$ có tỉ lệ nảy mầm cao nhất, khác biệt ý nghĩa thống kê $(\mathrm{p}<0,05)$ so với các nghiệm thức còn lại và đạt $93,3 \%$. Các nghiệm thức chủng dòng vi khuẩn này với mật số $10^{7}$ CFU.mL ${ }^{-1}, 10^{8}$ CFU.mL ${ }^{-1}, 10^{9}$ CFU.mL ${ }^{-1}$ có tỉ lệ nảy mầm hạt bắp thấp hơn so với nghiệm thức chủng vi khuẩn HH5 ở mật số $10^{6}$ CFU.mL ${ }^{-1}$, lần lượt đạt $80,0 \%, 76,7 \%$ và $76,7 \%$ và khác biệt không ý nghĩa thống kê $(p>0,05)$ khi so sánh với nhau và với nghiệm thức đối chứng không chủng vi khuẩn $(73,3 \%)$. Tương tự với dòng vi

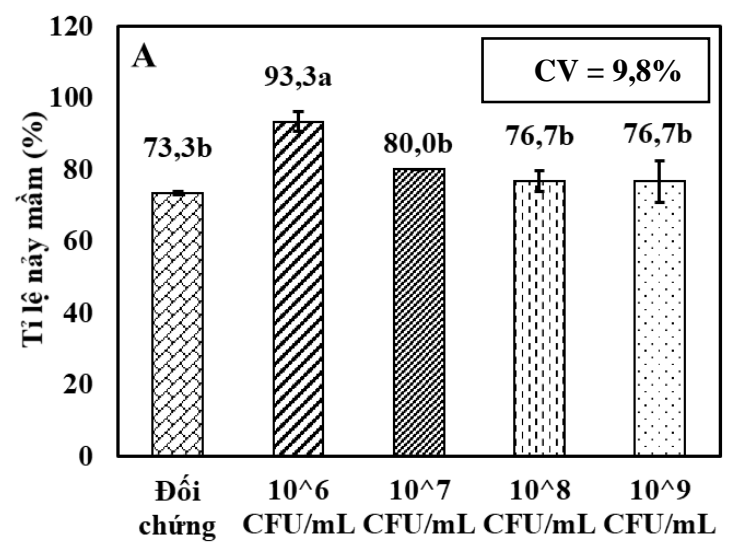

Nghiệm thức khuẩn HH5, dòng vi khuẩn tuyển chọn MT6 với nghiệm thức chủng mật số $10^{6} \mathrm{CFU} \cdot \mathrm{mL}^{-1}$ cũng cho tỉ lệ nảy mầm hạt bắp cao nhất, đạt $93,3 \%$ và khác biệt ý nghĩa thống kê $(\mathrm{p}<0,05)$ so với nghiệm thức đối chứng không chủng vi khuẩn $(73,3 \%)$ và nghiệm thức chủng với mật số $10^{9}$ CFU.mL ${ }^{-1}(80,0 \%)$. Trong khi nghiệm thức chủng dòng vi khuẩn MT6 ở mật số $10^{6} \mathrm{CFU} \cdot \mathrm{mL}^{-1}$ có tỉ lệ nảy mầm hạt bắp khác biệt không ý nghĩa thống kê ( $\mathrm{p}>0,05)$ khi so với các nghiệm thức chủng ở mật số $10^{7}$ CFU.mL ${ }^{-1}(86,7 \%)$ và $10^{8} \mathrm{CFU} \cdot \mathrm{mL}^{-1}(86,7 \%)$. Kết quả này phù hợp với nghiên cứu của Kiều Phương Nam (2010) cho thấy các dòng vi khuẩn Methylobacterium spp. từ lá cây có khả năng kích thích gia tăng tỉ lệ nảy mầm các hạt giống như đậu đũa, đậu xanh, đậu cove và cà chua. Tóm lại kết quả thí nghiệm này cho thấy mật số $10^{6} \mathrm{CFU} \cdot \mathrm{mL}^{-1}$ là mật số thích hợp nhất để chủng hai dòng vi khuẩn $\mathrm{HH} 5$ và $\mathrm{MT} 6$ vào hạt bắp giúp gia tăng tỉ lệ nảy mầm của hạt và có thể với mật sô $10^{6}$ CFU.mL ${ }^{-1}$ này vi khuẩn tổng hợp ra lượng phytorhormone vừa đủ để giúp kích thích tỉ lệ nảy mầm của hạt bắp tốt nhất.

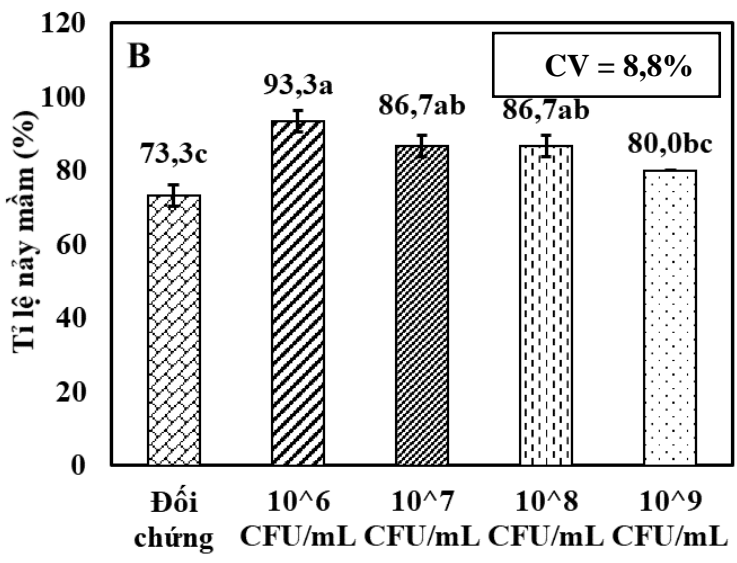

Nghiệm thức

Hình 3. Tỉ lệ nảy mầm của hạt bắp khi chủng với dòng vi khuẩn HH5 (A) và MT6 (B) ở các mật số vi khuẩn khác nhau $(\mathrm{n}=3)$

Ghi chú: Nhũng số có chũ theo sau khác nhau thì có khác biệt ý nghĩa thống kê ở mức 5\%

\section{4. Định danh hai dòng vi khuẩn tuyển chọn HH5 và MT6 có khả năng kích thích sinh trưởng cây trồng tốt nhẩt bằng phương pháp giải mã trình tự đoạn gene $16 \mathrm{~S}$ rRNA}

Hai dòng vi khuẩn được tuyển chọn $\mathrm{HH} 5$ và MT6 cho hiệu quả kích thích sinh trưởng hạt bắp tốt nhất được phân lập từ lá cây hoa hồng và cây mồng tơi. Hai dòng vi khuẩn này đều là vi khuẩn gram dương, tế bào dạng hình que và khuẩn lạc có dạng tròn, màu vàng nâu, hơi nhô, dạng bìa nguyên và bề mặt trơn.

Khi so sánh trình tự đoạn gene $16 \mathrm{~S}$ rRNA với cơ sở dữ liệu trên ngân hàng gene thế giới bằng chương trình BLAST (http://blast.ncbi.nlm.nih.gov/Blast. cgi.), kết quả cho thấy trình tự đoạn gene của 2 dòng vi khuẩn HH5 và MT6 lần lượt tương đồng với đoạn gene 16S rRNA của 2 loài vi khuẩn Curtobacterium citreum và Curtobacterium luteum với tính đồng hình lần lượt là $99 \%$ và $100 \%$. Ngoài ra, dựa vào thông tin về̀ hình thái khuẩn lạc và tế bào của hai 
dòng vi khuẩn này theo Yamada and Komagata (1972) cho thấy hai dòng vi khuẩn này đều có khuẩn lạc tròn, màu vàng nghệ, tế bào dạng hình que ngắn và thật sự giống với hình thái khuẩn lạc và tế bào của hai dòng vi khuẩn HH5 và MT6. Do đó, hai dòng vi khuẩn tuyển chọn này đều được nhận dạng như là hai dòng vi khuẩn thuộc chi vi khuẩn Curtobacterium và được định danh là Curtobacterium citreum $\mathrm{HH} 5$ và Curtobacterium luteum MT6 (Bảng 3).

Bảng 3. Tóm tắt kết quả định danh 2 dòng vi khuẩn tuyển chọn HH5 và MT6

\begin{tabular}{|c|c|c|c|c|c|}
\hline \multirow{2}{*}{ STT } & \multirow[t]{2}{*}{ Dòng } & \multirow{2}{*}{$\begin{array}{l}\text { Độ đồng } \\
\text { hình }(\%)\end{array}$} & \multicolumn{2}{|c|}{ Các dòng vi khuẩn trên cơ sở dữ liệu } & \multirow{2}{*}{-Định danh } \\
\hline & & & Vi khuẩn & Số đăng kí & \\
\hline 1 & HH5 & 99 & Curtobacterium citreum & NR_026156.1 & Curtobacterium citreum $\mathrm{HH} 5$ \\
\hline 2 & MT6 & 100 & Curtobacterium luteum & JQ660320.1 & Curtobacterium luteum MT6 \\
\hline
\end{tabular}

Các vi khuẩn thuộc chi Curtobacterium là vi khuẩn Gram dương, hiếu khí bắt buộc (Evtushenko \& Takeuchi, 2006), vi khuẩn không hình thành bào tử, do đó vi khuẩn thuộc chi Curtobacterium sống sót kém trong đất (Vidaver, 1982). Hầu hết vi khuẩn Curtobacterium có tác động tích cực đến sinh trưởng ở thực vât ngoại trừ dòng vi khuẩn $C$. flaccumfaciens là loài vi khuẩn thuộc chi Curtobacterium duy nhất gây bệnh ở thực vật (Young et al., 1996).

\section{KẾT LUẬN}

Các hệ vi khuẩn có nguồn gốc từ lá 16 loài thực vật khác nhau trong nghiên cứu này đều có khả năng kích thích gia tăng tỉ lệ nảy mầm và sinh trưởng của cây bắp. Từ 6 hệ vi khuẩn lá thực vật ưu tú nhất được tuyển chọn để phân lập vi khuẩn có khả năng kích thích sinh trưởng cây trồng đã phân lập được 28 dòng vi khuẩn. Chúng đa dạng về hình thái và màu sắc khuẩn lạc cũng như hình thái về tế bào, trong đó, chủ yếu có khuẩn lạc dạng hình tròn, màu trắng, trắng đục, vàng, hồng, gram dương, tế bào có dạng hình que ngắn và hình cầu. Trong đó, 2 dòng vi khuẩn ký hiệu HH5 và MT6 có nguồn gốc từ lá cây hoa hồng và cây mồng tơi thể hiện khả năng kích thích sinh trưởng cây bắp tốt nhất thông qua các chỉ tiêu về tỉ lệ nảy mầm, chiều dài rễ chính, số rễ và chiều cao chồi. Khả năng kích thích tỉ lệ nảy mầm hạt bắp tốt nhất của 2 dòng vi khuẩn này được xác định ở mật số $10^{6} \mathrm{CFU} \cdot \mathrm{mL}^{-1}$. Dựa vào kết quả giải trình tự đoạn gene $16 \mathrm{~S}$ RNA cả 2 dòng vi khuẩn được nhận dàng đều thuộc chi Curtobacterium và được định danh như Curtobacterium citreum $\mathrm{HH} 5$ và Curtobacterium luteum MT6. Cả 2 dòng vi khuẩn này có tiềm năng ứng dụng cao trong việc tạo ra chế phẩm sinh học kích thích sinh trường cây trồng và thân thiện với môi trường.

\section{TÀI LIỆU THAM KHẢO}

Araújo, W. L., Marcon, J., Maccheroni, W., van Elsas, J. D., van Vuurde, J. W. and Azevedo, J. L. (2002). Diversity of endophytic bacterial populations and their interaction with Xylella fastidiosa in citrus plants. Applied and

Environmental Microbiology, 68(10), 4906-4914.

Behrendt, U., Ulrich, A., Schumann, P., Naumann, D. and Suzuki, K. I. (2002). Diversity of grassassociated Microbacteriaceae isolated from the phyllosphere and litter layer after mulching the sward; polyphasic characterization of Subtercola pratensis sp. nov., Curtobacterium herbarum sp. nov. and Plantibacter flavus gen.

nov.. International Journal of Systematic and Evolutionary Microbiology, 52(5), 1441-1454.

Bulgari, D., Casati, P., Crepaldi, P., Daffonchio, D., Quaglino, F., Brusetti, L. and Bianco, P. A. (2011). Restructuring of endophytic bacterial communities in grapevine yellows-diseased and recovered Vitis vinifera L. plants. Applied and Environmental Microbiology, 77 (14), 5018-5022.

Evtushenko, L. I. and Takeuchi, M. (2006). The family microbacteriaceae. The prokaryotes: a handbook on the biology of bacteria, 3, 1020-1098.

Holland, M. A. and Polacco, J. C. (1994). PPFMs and other covert contaminants: Is there more to plant physiology than just plant? Annual Review of Plant Biology, 45, 197-209.

Holland, M. A. (1997). Are cytokinin produced by plant? Plant Physiology, 115, 865-868.

Holland, M. A., Davis, R., Moffitt, S., O'Laughlin, K., Peach, D., Sussan, S., and Tayman, B. (2000). Using "leaf prints" to investigate a common bacterium. The American Biology Teacher, 62(2), 128-131.

Ihrmark, K., Cruz-Martinez, K., Friberg, H., Kubartova, A., Schenck, J., Strid, Y., Stenlid, J. and Clemmensen, K. E. (2012). New primers to amplify the fungal ITS2 region-evaluation by 454-sequencing of artificial and natural communities. FEMS Microbiology Ecology, 82(3), 666-677.

Kiều Phương Nam, Đỗ Thị Di Thiện, Trần Minh Tuấn \& Bùi Văn Lệ. (2009). Ảnh hưởng của vi khuẩn Methylobacterium radiotolerans 1019 lên sự phát sinh cơ quan ở thực vật. Tạp chí khoa học Lâm Nghiệp, 4, 1071-1076.

Kiều Phương Nam, Hồ Lê Trung Hiếu, Trần Minh Tuấn, Đỗ Thị Di Thiện \& Bùi Văn Lệ. (2010). 
Khả năng ứng dụng vi khuẩn Methylobacterium spp. trong việc gia tăng tỉ lệ nảy mầm của hạt giống cây trồng. Tạp chi phát triển khoa họ và công nghẹ,13, 49-57.

Lacava, P. T., Li, W., Arau'jo, W. L., Azevedo, J. L. and Hartung, J. S. (2007). The endophyte Curtobacterium flaccumfaciens reduces symptoms caused by Xylella fastidiosa in Catharanthus roseus. Journal of MicrobiologySeoul, 45(5), 388-393.

Madhaiyan, M., Poonguzhali, S., Ryu, J. and Sa, T. (2006). Regulation of ethylene levels in canola (Brassica campestris) by 1-aminocyclopropane1-carboxylate deaminase containing Methylobacterium fujisawaense. Planta, 224(2), 268-278.

Maliti, C. M. (2000). Physiological and Biochemical Effects of Methylobacterium sp. strains and foliarapplied methanol on growth and development of rice Oryza sativa L. Doctoral dissertation. City University of New York. New York.

Mayer E., de Quadros, P. D., and Fulthorpe, R. (2019). Plantibacter flavus, Curtobacterium herbarum, Paenibacillus taichungensis, and Rhizobium selenitireducens endophytes provide host-specific growth promotion of Arabidopsis thaliana, basil, lettuce, and bok choy plants. Applied and Environmental Microbiology, 85(19), e00383-19.

Miles, A. A., Misra, S. S. and Irwin, J. O. (1938). The estimation of the bactericidal power of the blood. The Journal of Hygiene, 38(6), 732-749.

Sturz, A. V., Christie, B. R., Matheson, B. G. and Nowak, J. (1997). Biodiversity of endophytic bacteria which colonize red clover nodules, roots, stems and foliage and their influence on host growth. Biology and Fertility of Soils, 25(1), 13-19.

Sy, A., Giraud, E., Jourand, P., Garcia, N., Willems, A., De Lajudie, P. and Dreyfus, B. (2001).

Methylotrophic Methylobacterium bacteria nodulate and fix nitrogen in symbiosis with legumes. Journal of Bacteriology, 183(1), 214-220.

Tổng cục Môi trường. (2015). Hiện trạng ô nhiễm môi trường do hóa chất bảo vệ thực vật tồn lưu thuộc nhóm chất hữu cơ khó phân hủy tại Việt Nam. Tổng cục môi trường. Hà Nội.

Trung tâm Thông tin và Thống kê Khoa học và Công nghệ (2019). Xu hướng ứng dụng chế phẩm vi sinh trong xử lý phụ phẩm nông nghiệp. Sở Khoa học và Công nghệ Thành phố Hồ Chí Minh. Thành phố Hồ Chí Minh.

Urquhart, E. J. and Punja, Z. K. (2002). Hydrolytic enzymes and antifungal compounds produced by Tilletiopsis species, phyllosphere yeasts that are antagonists of powdery mildew fungi. Canadian Journal of Microbiology, 48(3), 219-229.

Weisburg, W.G., Barns, S.M., Pelletier, D.A. and Lane, D.J. (1991). 16S ribosomal DNA amplification for phylogenetic study. Journal of Bacteriology, 173(2), 697-703.

Vidaver, A. K. (1982). The plant pathogenic corynebacteria. Annual Reviews in Microbiology, 36(1), 495-517.

Yamada, K., and Komagata, K. (1972). Taxonomic studies on coryneform bacteria. The Journal of General and Applied Microbiology, 18(6), 417-431.

Young, J. M., Saddler, G. S., Takikawa, Y., De Boer, S. H., Vauterin, L., Gardan, L., and Stead, D. E. (1996). Names of plant pathogenic bacteria 1864-1995. Review of Plant Pathology, 75(9), 721-763. 